\title{
IN VITRO ANTI-NEUROINFLAMMATORY EFFECT OF GENISTEIN (4',5,7- TRIHYDROXYISOFLAVONE) ON MICROGLIA HMC3 CELL LINE, AND IN SILICO EVALUATION OF ITS INTERACTION WITH ESTROGEN RECEPTOR- $\beta$
}

\author{
BURHAN MA'ARIF', FAISAL A. MUSLIKH'1, WIRDA ANGGRAINI'1, MAXIMUS M. TAEK², HENING LASWATI³, \\ MANGESTUTI AGIL ${ }^{*}$
}

1Department of Pharmacy, Faculty of Medical and Health Science, Maulana Malik Ibrahim State Islamic University, Malang, Indonesia, 2Department of Chemistry, Faculty of Mathematics and Natural Sciences, Widya Mandira Catholic University, Kupang, Indonesia, ${ }^{3}$ Department of Physical Medicine and Rehabilitation, Faculty of Medicine, Airlangga University, Surabaya, Indonesia, ${ }^{4}$ Department of Pharmacognosy and Phytochemistry, Faculty of Pharmacy, Airlangga University, Surabaya, Indonesia

Email: mmangestuti@yahoo.com

Received: 20 Aug 2021, Revised and Accepted: 01 Oct 2021

ABSTRACT

Objective: This study was aimed to evaluate the role of genistein or 4',5,7-trihydroxyisoflavone as a phytoestrogen in the treatment of estrogen deficiency-induced neuroinflammatory. The specific objectives of this study were to determine the anti-neuroinflammatory effect of genistein through measurement of MHC II and Arg1 expressions on microglia HMC3 cell line, as well as to prove that the effect occurs in an ER-dependent manner, through the measurement of free-ER $\beta$ expression.

Methods: The cells were cultured in 24-well microplates, induced with $10 \mathrm{ng}$ IFN- $\gamma$, and incubated for 24 h to activate the cell to $\mathrm{M}_{1}$ phenotype which has pro-inflammatory characteristics. Genistein with a concentration of $50 \mu \mathrm{M}$ was added to the cells. The expression of MHC II, Arg1, and free-ER $\beta$ as markers was tested through an immunocytochemistry method and measured using the CLSM instrument. In silico approach was also conducted to determine the interaction between genistein and ER $\beta$, compared to 17 $\beta$-estradiol. Genistein structure was prepared with Avogadro 1.0.1, and molecular docking was done using PyRx 0.8 software. Biovia Discovery Studio Visualizer 2016 was used to visualize the structure of genistein against 30LS protein. The physicochemical characteristics of genistein were analyzed using the SwissADME web tool.

Results: Genistein can decrease MHC II expression and increase Arg1 expression in microglia HMC3 cells compared to negative controls (p<0.005), with expression value of $472.577 \pm 26.701 \mathrm{AU}$ and 114.299 $\pm 6.578 \mathrm{AU}$. But, genistein cannot decrease the free-ER $\beta$ expression in cells (p<0.005). The results of in silico analysis showed that genistein is an ER $\beta$ agonist.

Conclusion: Genistein shows anti-neuroinflammatory effects by decreasing the MHC II expression and increasing Arg1 expression in the microglia HMC3 cell line. However, this effect does not occur through the binding of genistein to ER $\beta$, but it is likely to occur through the binding of genistein with other types of ER.

Keywords: Genistein, Anti-neuroinflammatory, Microglia HMC3 cell line, Phytoestrogens

(C) 2021 The Authors. Published by Innovare Academic Sciences Pvt Ltd. This is an open access article under the CC BYlicense (https://creativecommons.org/licenses/by/4.0/) DOI: https://dx.doi.org/10.22159/ijap.2021.v13s4.43855 Journal homepage: https://innovareacademics.in/journals/index.php/ijap

\section{INTRODUCTION}

The global prevalence of neurodegenerative diseases has been increasing in recent decades [1]. One of the main causes of neurodegenerative diseases is neuroinflammatory. For postmenopausal women, neuroinflammatory is triggered by estrogen deficiency. In the other words, estrogen deficiency triggers postmenopausal women to be prone to neuroinflammatory, which can causes some neurodegenerative disorders [2-4]. In neuroinflammatory, there is an increase of the number of microglia cells that are activated in the $\mathrm{M}_{1}$ polarity state which has pro-inflammatory characteristics due to estrogen deficiency. The increasing of activated microglia cells then causes an increase in inflammatory cytokines, such as interleukin-1 (IL-1), IL-6, tumor necrosis factor- $\alpha$ (TNF- $\alpha$ ), and nitric oxide (NO), as well as major histocompatibility complex II (MHC II) [5, 6]. Continuous M1 polarity state activation of microglia cells can cause prolonged inflammation and induces hippocampal neuron cell death leading to decreased cognitive function [7-9].

Inhibition of neuroinflammatory progression can be conducted to prevent neurodegenerative diseases. The logic method is to provide estrogen replacement compounds to activate microglia cells towards the $\mathrm{M}_{2}$ polarity state, which has anti-inflammatory characteristics. Activation of microglia cells in $\mathrm{M}_{1}$ polarity causes pro-inflammatory conditions that are characterized by an increase of inflammatory cytokines. In contrast, activation of microglia cells in $\mathrm{M}_{2}$ polarity causes an anti-inflammatory condition characterized by decrease of inflammatory cytokines, as well as an increase in the expression of IL10 , IL-13, T-cell growth factor- $\beta$ (TGF- $\beta$ ), and arginase 1 (Arg1) [7-9].
Phytoestrogens are compounds derived from plants which have similar structure to estrogen. Biologically, they can replace the function of estrogen in maintaining homeostasis in the brain, both in conjunction with estrogen receptors (ER-dependent) or not in conjunction with the receptors (ER-independent) [10]. Thus, using phytoestrogens can be an alternative treatment for estrogen deficiency-induced neuroinflammatory [11]. Genistein or 4',5,7trihydroxyisoflavone with molecular formula $\mathrm{C}_{15} \mathrm{H}_{10} \mathrm{O}_{5}$ (fig. 1) is an example of phytoestrogens. Genistein is a plant naturally occurring compound belonging to the isoflavone group. This compound can be found in various species of Leguminoceae or Fabaceae [12]. Genistein was known to be able to bind estrogen receptors (ER) and produce many estrogenic effects [13-16], thus, it is potential to be used as an agent of neuroinflammatory therapy.

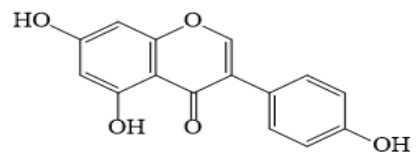

Fig. 1: Molecular structure of genistein

This research aimed to determine the anti-neuroinflammatory effect of genistein through measurement of MHC II and Arg1 expression on human microglia clone 3 (HMC3) cell line (ATCC $\AA$ CRL-3304 ${ }^{\mathrm{TM}}$ ) [17] in an in vitro testing, as well as to know that the effect occurs in an 
ER-dependent manner, through the measurement of free-ER $\beta$ expression. The estrogen deficiency condition was created by induction of interferon- $\gamma$ (IFN- $\gamma$ ) to the microglia HMC3 cells culture, and the measurement of markers was done using immunocytochemistry method and confocal laser scanning microscope (CLSM) instrument.

In addition to in vitro testing, we also confirmed the interaction pattern between genistein and the estrogen receptor in silico, by conducting molecular docking between genistein and 30LS proteincontaining histidine, glutamine and arginine on the active site of this protein. Research on genistein as a neuroprotective agent has been done quite a lot, but the effect of genistein as a neuroprotective through an anti-neuroinflammatory mechanism in HMC3 microglia cells has never been done before.

\section{MATERIALS AND METHODS}

\section{Materials}

The microglia HMC cell line was purchased from American Type Culture Collection (ATCC $₫$ CRL-3304 ${ }^{\mathrm{TM}}$ ) Manassas, USA [17]. Genistein, eagle's minimum essential medium (EMEM), dimethyl sulfoxide (DMSO), paraformaldehyde (PFA), fetal bovine serum (FBS), phosphate buffer saline (PBS), serum bovine albumin (BSA), Tween 80, IFN- $\gamma$, Triton X100, anti-rabbit secondary antibody fluorescein isothiocyanate (FITC), anti-mouse secondary antibody rhodamine, were purchased from Sigma-Aldrich, Missouri, USA; penicillin, streptomycin, anti-rabbit MHC II primary antibody (ab114224), anti-rabbit ER $\beta$ primary antibody (ab3576), were purchased from Abcam, Boston, USA; anti-mouse Arg1 primary antibody (sc-166920) was purchased from Santa Cruz Biotechnology, California, USA.

\section{Cell culture}

Preparation of cell culture was conducted according to a procedure developed by Central Laboratory of Life Sciences, Universitas Brawijaya, Indonesia [18-20]. Microglia HMC3 cell line was cultured in a $25 \mathrm{~cm}^{2}$ flask containing \pm 250.000 cells with a complete medium containing $5 \mathrm{ml}$ EMEM, 10\% FBS, and 1\% penicillin-streptomycin. The cells culture was then incubated in a $5 \% \mathrm{CO} 2$ incubator at $37^{\circ} \mathrm{C}$ for $6 \mathrm{~d}$, until the cells growth reached $80 \%$ confluent in the flask.

\section{Genistein solution}

A $50 \mu \mathrm{M}$ genistein sample solution was prepared by mix $40 \mu \mathrm{l}$ of 1 mmol genistein solution with $0.8 \mathrm{ml}$ complete medium containing 5 $\mathrm{ml}$ EMEM, $10 \% \mathrm{FBS}$, and $1 \%$ penicillin-streptomycin.

\section{Measurement of MHC II, Arg1, and free-ER $\beta$}

The effects of genistein on microglia HMC3 cell lines were measured according to a procedure developed by Central Laboratory of Life Sciences, Universitas Brawijaya, Indonesia [19-20]. After cultured cells reach $80 \%$ confluence, then the induction of IFN- $\gamma$ was performed. $10 \mathrm{ng}$ IFN- $\gamma$ was added into the cells, and the culture was incubated for $24 \mathrm{~h}$. The cultured cells were then rinsed with PBS and treated with $50 \mu \mathrm{M}$ genistein for $48 \mathrm{~h}$. The cells then rinsed again with PBS and fixed with $4 \%$ PFA, Triton X100, BSA, and anti-rabbit MHC II primary antibody for single staining methods. After the previous procedure, a double staining method was performed in different 24-well microplates with anti-mouse Arg1 primary antibody and anti-rabbit ER $\beta$ primary antibody. The cells were then incubated at $4{ }^{\circ} \mathrm{C}$ overnight. As the final step of the procedures, an anti-rabbit secondary antibody FITC and anti-mouse secondary antibody rhodamine were added before the cells were analyzed using a CLSM instrument at $488 \mathrm{~nm}$ and $543 \mathrm{~nm}$.

\section{In silico evaluation}

The three-dimensional structure of estrogen receptor (ER $\beta$ ) was obtained from Protein Data Bank (http://www.rcsb.org) with code 30LS [21]. Initial preparation was done to separate the natural ligand of ER $\beta$ that is $17 \beta$-estradiol-from the protein using Biovia Discovery Studio Visualizer 2016. The natural ligand and genistein molecular structures were prepared with Avogadro 1.90.0 for energy optimization by using the MMF94s method. Molecular docking and simulation of the docking were conducted using PyRx 0.8 software [22, 23]. The complex of receptor-ligand obtained from docking simulation was visualized using Biovia Discovery Studio Visualizer 2016. Further analysis was done using the SwissADME web tool to predict the physicochemical properties of genistein and the natural ligand.

\section{RESULTS}

Visualization of marker expression in microglia HMC3 cells can be seen in fig. 2 and fig. 3 , while the results of the analysis of marker expression are as shown in table 1 . In fig. 2 and fig. 3 , the treatment of genistein decreased MHC II expression significantly compared to negative control with $\mathrm{p}=0.002$. The decrease in MHC II expression was indicated by the decrease in the fluorescence intensity of the microglia HMC3 cell line. The induction of genistein increases Arg1 expression significantly compared to negative control with $\mathrm{p}<0.001$, as well as increases the freeER $\beta$ expression significantly compared to negative control with $\mathrm{p}<0.001$. The increase in Arg1 expression was indicated by an increase in the red color intensity of microglia HMC3 cell line, while the increase in free-ER $\beta$ expression was indicated by an increase in the green color intensity of the microglia HMC3 cell line.

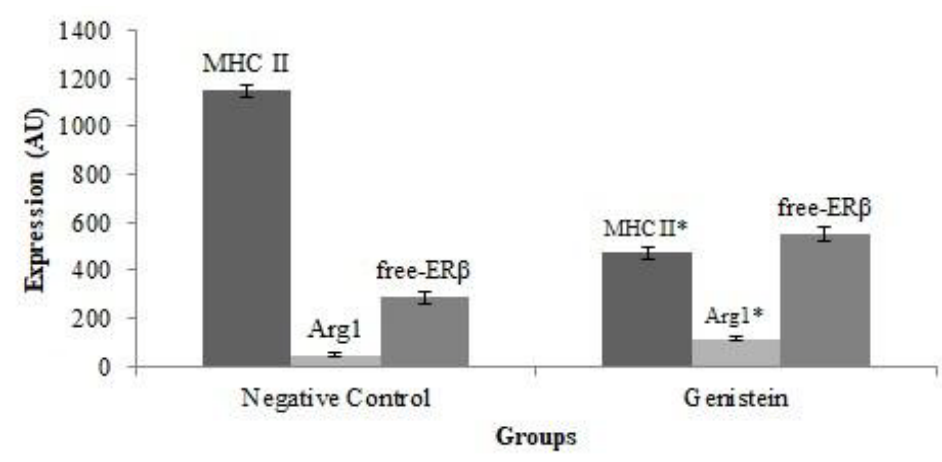

Fig. 2: The expression of MHC II, Arg1 and Free-ERß after genistein induction in microglia HMC3 cell line. Each value is expressed as mean \pm SD. Significant differences compared to a negative control $(*)$ at $p<0.05$

Table 1: The expression value of MHC II, Arg1, and free-ERß in arbitrary unit (AU) after genistein induction in microglia HMC3 cell line

\begin{tabular}{llll}
\hline Groups & MHC II (AU) & Arg1 (AU) & Free-ER $\boldsymbol{\beta}$ (AU) \\
\hline Negative control & $1149.399 \pm 25.810$ & $47.080 \pm 6.799$ & $287.735 \pm 26.107$ \\
Genistein & $472.577 \pm 26.701^{*}$ & $114.299 \pm 6.578^{*}$ & $553.295 \pm 29.694^{*}$ \\
\hline
\end{tabular}

Note: Each value is expressed as mean \pm SD. Significant differences compared to negative control $(*)$ at $p<0.05$. 

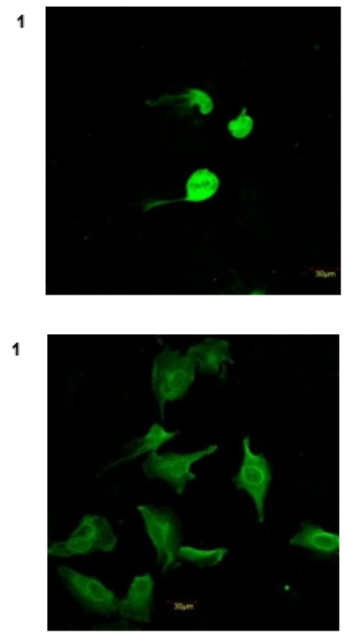

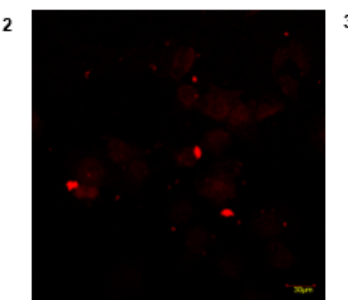

A

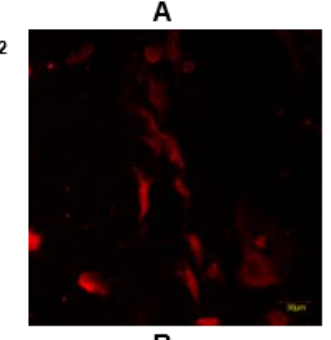

B
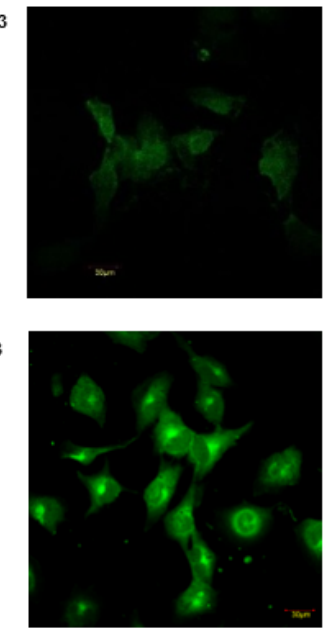

Fig. 3: The immunofluorescence visualization of markers in microglia HMC3 cell lines. (A) Negative control; (B) Genistein: (1) MHC II expression, (2) Arg1 expression, (3) Free-ERß expression

The results of in silico evaluation on the interaction of both genistein and natural ligand ( $17 \beta$-estradiol) with the ER $\beta$ can be seen in table 2. A comparison of pharmacophore distance (bond distance) and amino acid bonds between 30LS protein and $17 \beta$-estradiol and genistein is as shown in fig. 4. Compounds or ligands are categorized as agonists of the $17 \beta$-estradiol if they have a bond distance and pharmacophore groups similar to $17 \beta$-estradiol. Besides that, they should bind the same amino acids in the 30LS protein as $17 \beta$ estradiol. That is, if it has a bond distance of about $10.862 \AA$, and has one pharmacophore group that binds His 475, and another pharmacophore group binds Glu 305 or Arg 346. These results indicate that genistein is an ER $\beta$ agonist like $17 \beta$-estradiol; thus, it has a high potential to be used as a drug in neuroinflammatory therapy.

Table 2: Docking parameters of the interactions of genistein and 17 $\beta$-estradiol with 30LS protein

\begin{tabular}{|c|c|c|c|c|c|c|c|c|c|}
\hline \multirow[t]{2}{*}{ Ligand } & \multirow{2}{*}{$\begin{array}{l}\text { Binding } \\
\text { affinity } \\
\text { (kcal/mol) }\end{array}$} & \multirow{2}{*}{$\begin{array}{l}\text { Rmsd } \\
\text { average } \\
(\AA)\end{array}$} & \multirow{2}{*}{$\begin{array}{l}\text { Amino acid and bond } \\
\text { type }\end{array}$} & \multirow{2}{*}{$\begin{array}{l}\text { Pharma- } \\
\text { cophore } \\
\text { distance }(\AA ̊)\end{array}$} & \multirow{2}{*}{$\begin{array}{l}\text { TPSA } \\
\leq 140\end{array}$} & \multicolumn{4}{|c|}{ Lipinski's rule of five } \\
\hline & & & & & & $\begin{array}{l}\text { BM } \\
\text { (g/mol) }\end{array}$ & $\log P$ & $\begin{array}{l}\text { H-bond } \\
\text { acceptors }\end{array}$ & $\begin{array}{l}\text { H-bond } \\
\text { donors }\end{array}$ \\
\hline Genistein & -8.6 & 0.000 & $\begin{array}{l}\text { His475 (Hydrogen) } \\
\text { Glu305 (Hydrogen) } \\
\text { Arg } 346 \text { (Unfavorable) }\end{array}$ & 12.136 & 90.90 & 270.24 & 0.52 & 5 & 3 \\
\hline $\begin{array}{l}17 \beta- \\
\text { estradiol }\end{array}$ & -10.5 & 0.000 & $\begin{array}{l}\text { His475 (Hydrogen) } \\
\text { Glu305 (Hydrogen) } \\
\text { Arg } 346 \text { (Hydrogen) }\end{array}$ & 10.862 & 40.46 & 272.38 & 3.53 & 2 & 2 \\
\hline
\end{tabular}

Criteria: TPSA $\leq 140 ; \mathrm{MW} \leq 500 \mathrm{~g} / \mathrm{mol}$; $\log \mathrm{P} \leq 5$; H-bond acceptors $\mathrm{N}$ or $\mathrm{O} \leq 10$; H-bond donors $\mathrm{NH}$ or $\mathrm{OH} \leq 5$.

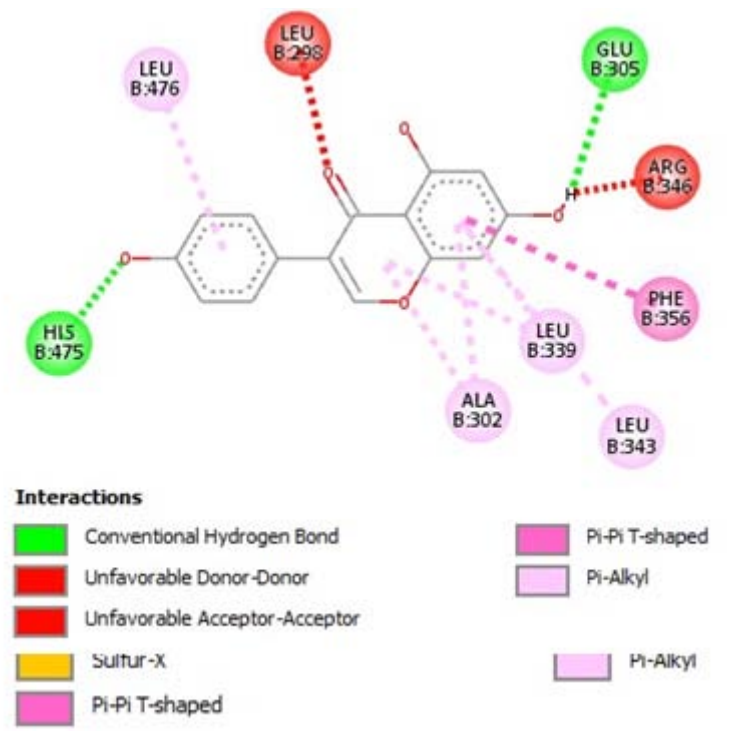

Fig. 4: (A) Binding mode of $17 \beta$-estradiol bond with the amino acid in the 3 OLS protein. The $17 \beta$-estradiol binds amino acid with a pharmacophore distance (bond distance) of $10.862 \AA$, and binds his 475, Glu 305, and Arg 346 with hydrogen bonds. (B) Genistein binds amino acid with bond distance of $12.135 \AA$, and binds His 475 and Glu 305 with hydrogen bonds, and binds Arg 346 with an unfavorable bond 


\section{DISCUSSION}

The anti-neuroinflammatory effect of genistein occurs through the induction of inhibition of HMC3 microglia cells activation to a proinflammatory state $\left(M_{1}\right.$ polarity), which is characterized by inhibition of MHC II expression. As well as induction of increase of HMC3 microglia cells activation to an anti-inflammatory state $\left(M_{2}\right.$ polarity), which is characterized by an increase in Arg1 expression. Anti-neuroinflammatory activity was predicted to occur in an ERdependent manner, so we also examined it using the ER $\beta$ as marker.

In this study, the model of inflammation-induced estrogen deficiency was made by induction of IFN- $\gamma[17,24,25]$. IFN- $\gamma$ binds toll-like receptor 4 (TLR4) and activates nuclear factor kappa-light-chainenhancer of activated B cells (NF- $\mathrm{KB}$ ). Both estrogen deficiency and induction of IFN- $\gamma$ on microglia HMC3 cells were known to be able to activate the cells to $\mathrm{M}_{1}$ polarity conditions, where active microglia HMC3 cells have pro-inflammatory characteristics $[7,9]$.

Anti-neuroinflammatory activity occurs when genistein was given to microglia HMC3 cells as a treatment and replaces the function of estrogen in regulating the activity of the cell $[11,26-28]$. In this process, there was an activation of microglia HMC3 cells to M2 polarity condition, where active microglia HMC3 cells have antiinflammatory characteristics [7]. The increase of bonding between genistein and ER $\beta$ in the ER-dependent nuclear-initiated estrogen signaling pathway can activate ER $\beta$ in the cytoplasm to translocate in the nucleus, which causes several mechanisms such as inhibition of inhibitor of kappa B kinase (IкK) activation, inhibition of phosphorylation inhibitor of kappa B (ІкB), inhibition of NF-кB activation, and induces down-regulation of the human leukocyte antigen B27 (HLA-B27) gene, which causes a decrease in the production of pro-inflammatory cytokines while production of antiinflammatory agents is increase $[2,3,5,10]$.

The prediction of genistein activity can be carried out with in silico analysis. This method assists in simple predictions by correlating the structure and physicochemical properties with application analysis regarding its potential as medicine [29]. In silico studies were used to predict the activity of genistein in binding to ER $\beta$ at the molecular level, whether genistein is an ER $\beta$ agonist and is able to provide estrogenic effects such as $17 \beta$-estradiol or not. This in silico results were then used to explain the mechanism that occurs in the in vitro results.

The physicochemical properties of genistein were analyzed in silico based on the criteria of topological polar surface area (TPSA) value and Lipinski's rule of five. TPSA is a value that describes the ability of a compound to penetrate the membrane. The compounds are categorized as being able to penetrate the cell membrane if it has a TPSA value $<140 \AA^{2}[30]$. From the physicochemical analysis, it was shown that genistein has TPSA value $<140 \AA^{2}$, so it meets the criterion. The results of physicochemical analysis also indicate that genistein meets the criteria of Lipinski's rule of five, so it has the potential to be developed as an oral drug [31,32].

In connecting the results of in vitro and in silico studies, we found something interesting. In the results of measuring the expression of Arg1 and MHC II in vitro, genistein has been shown to have antineuroinflammatory activity. Based on literature study and in silico results, this anti-neuroinflammatory activity occurs in an ERdependent manner in which genistein bind to the ER. However, in vitro ER $\beta$ measurements showed that genistein could not increase the expression of free ER compared to control, that means genistein did not bind significantly to ER $\beta$. Through a literature study, we found that genistein can bind to G-protein coupled estrogen receptor (GPER) with an effective and high-affinity bonding, better than to ER $\beta[33,34]$. Thus, the activity of decreasing MHC II expression and increasing Arg1 by genistein is likely caused by the binding of genistein to GPER. In microglia cells and neurons, GPER is highly expressed and is responsible for ER-dependent mechanisms of nonclassical (or non-genomic) pathways [35, 36], such as antineuroinflammatory activity.

\section{CONCLUSION}

Genistein shows anti-neuroinflammatory effects by decreasing the MHC II expression and increasing Arg1 expression in microglia
HMC3 cell line, but the effect seems not to occur through the binding of genistein to ER $\beta$. However, further study about the molecular interaction of genistein with other estrogen receptors is needed.

\section{FUNDING}

Nil

\section{AUTHORS CONTRIBUTIONS}

All the authors contributed equally.

\section{CONFLICT OF INTERESTS}

\section{Declared none}

\section{REFERENCES}

1. Prince M, Prina M. The epidemiology and impact of migraine. Migraine and other headache disorders: 2015. p. 47-60.

2. Au A, Feher A, McPhee L, Jessa A, Oh S, Einstein G. Estrogens, inflammation and cognition. Front Neuroendocrinol. 2016;40:87100. doi: 10.1016/j.yfrne.2016.01.002, PMID 26774208.

3. Engler Chiurazzi EB, Brown CM, Povroznik JM, Simpkins JW Estrogens as neuroprotectants: estrogenic actions in the context of cognitive aging and brain injury. Prog Neurobiol. 2017;157;Suppl 1:188-211. doi: 10.1016/ j.pneurobio.2015.12.008, PMID 26891883.

4. Varshney M, Nalvarte I. Genes, gender, environment, and novel functions of estrogen receptor beta in the susceptibility to neurodevelopmental disorders. Brain Sci. 2017;7(3);Suppl 3. doi: 10.3390 /brainsci7030024, PMID 28241485.

5. Abu-Taha M, Rius C, Hermenegildo C, Noguera I, Cerda-Nicolas JM, Issekutz AC, Jose PJ, Cortijo J, Morcillo EJ, Sanz MJ. Menopause and ovariectomy cause a low grade of systemic inflammation that may be prevented by chronic treatment with low doses of estrogen or losartan. J Immunol. 2009;183(2);Suppl 2:1393-402. doi: 10.4049/jimmunol.0803157, PMID 19553526.

6. Arcuri C, Mecca C, Bianchi R, Giambanco I, Donato R. The pathophysiological role of microglia in dynamic surveillance, phagocytosis and structural remodeling of the developing CNS. Front Mol Neurosci. 2017;10:191. doi: 10.3389/ fnmol.2017.00191, PMID 28674485.

7. Cherry JD, Olschowka JA, O'Banion MK. Neuroinflammation and M2 microglia: the good, the bad, and the inflamed. J Neuroinflammation. 2014;11;Suppl 1:98. doi: 10.1186/17422094-11-98, PMID 24889886.

8. Yang Z, Ming XF. Functions of arginase isoforms in macrophage inflammatory responses: impact on cardiovascular diseases and metabolic disorders. Front Immunol. 2014;5:533. doi: 10.3389/fimmu.2014.00533, PMID 25386179.

9. Mizuno T. Neuron-microglia interactions in neuroinflammation. Clin Exp Neuroimmunol. 2015;6(3):22531. doi: $10.1111 /$ cen3.12228.

10. Cui J, Shen Y, Li R. Estrogen synthesis and signaling pathways during aging: from periphery to brain. Trends Mol Med. 2013;19(3);Suppl 3:197-209. doi: 10.1016/j.molmed.2012.12.007, PMID 23348042.

11. Yang TS, Wang SY, Yang YC, Su CH, Lee FK, Chen SC, Tseng CY, Jou HJ, Huang JP, Huang KE. Effects of standardized phytoestrogen on Taiwanese menopausal women. Taiwan J Obstet Gynecol. 2012;51(2);Suppl 2:229-35. doi: 10.1016/j.tjog.2012.04.011, PMID 22795099.

12. Kim M, Lim J, Lee JH, Lee KM, Kim S, Park KW, Nho CW, Cho YS. Understanding the functional role of genistein in the bone differentiation in mouse osteoblastic cell line MC3T3-E1 by RNA-seq analysis. Sci Rep. 2018;8(1):3257. doi: 10.1038/s41598-018-21601-9. PMID 29459627.

13. Donzelli A, Braida D, Finardi A, Capurro V, Valsecchi AE, Colleoni M, Sala M. Neuroprotective effects of genistein in Mongolian gerbils: estrogen receptor- $\beta$ involvement. J Pharmacol Sci. 2010;114(2);Suppl 2:158-67. doi: 10.1254/jphs.10164fp, PMID 20962454.

14. Agrawal JSS, Saxena S, Sharma A. Phytoestrogen "genistein": its extraction and isolation from soybean seeds. Int J Pharmacogn Phytochem Res. 2015;7Suppl 6:1121-6. 
15. Ganai AA, Farooqi H. Bioactivity of genistein: a review of in vitro and in vivo studies. Biomed Pharmacother. 2015;76:30-8. doi: 10.1016/j.biopha.2015.10.026, PMID 26653547.

16. Yu J, Bi X, Yu B, Chen D. Isoflavones: anti-inflammatory benefit and possible caveats. Nutrients. 2016;8(6);Suppl 6:1-16. doi: 10.3390/nu8060361, PMID 27294954.

17. ATCC. HMC3 (ATCC $®$ CRL-3304 ${ }^{\mathrm{TM}}$ ). American Type Culture Collection [internet]; 2016. Available from: https://www.atcc.org/. [Last accessed on 10 Nov 2021]

18. Prosedur CCRC tetap uji sitotoksisitas metode MTT. Universitas gajah Mada; 2013.

19. Ma'arif B, Agil M, Laswati H. The enhancement of Arg1 and activated ER $\beta$ expression in microglia HMC3 by induction of 96\% ethanol extract of Marsilea crenata Presl. leaves. J Basic Clin Physiol Pharmacol. 2020;30(6). doi: 10.1515/jbcpp-20190284, PMID 31981453.

20. Ma'arif B, Mirza DM, Hasanah M, Laswati H, Agil M. Antineuroinflammation activity of n-butanol fraction of Marsilea crenata Presl. in microglia HMC3 cell line. J Basic Clin Physiol Pharmacol. 2020;30(6). doi: 10.1515/jbcpp-20190255 , PMID 31967965.

21. Möcklinghoff S, Rose R, Carraz M, Visser A, Ottmann C, Brunsveld L. Synthesis and crystal structure of a phosphorylated estrogen receptor ligand-binding domain. Chembiochem. 2010;11(16);Suppl 16:2251-4. doi: 10.1002/cbic.201000532, PMID 20922740.

22. Trott O, Olson AJ. AutoDock Vina: improving the speed and accuracy of docking with a new scoring function, efficient optimization, and multithreading. J Comput Chem. 2010;31(2);Suppl 2:455-61. doi: 10.1002/jcc.21334, PMID 19499576.

23. Dallakyan S, Olson A. Participation in global governance: coordinating "the voices of those most affected by food insecurity." Global Food Security Governance. 2015;1263:1-11.

24. Pfeffer LM. The role of nuclear factor $\kappa b$ in the interferon response. J Interferon Cytokine Res. 2011;31(7);Suppl 7:553-9. doi: 10.1089/jir.2011.0028, PMID 21631354.

25. Vagaska B, New SE, Alvarez-Gonzalez C, D’Acquisto F, Gomez SG, Bulstrode NW, Madrigal A, Ferretti P. MHC-class-II are expressed in a subpopulation of human neural stem cells in vitro in an IFN $\gamma$ independent fashion and during development. Sci Rep. 2016;6:24251. doi: 10.1038/srep24251. PMID 27080443.

26. Cos P, De Bruyne T, Apers S, Vanden Berghe DV, Pieters L, Vlietinck AJ. Phytoestrogens: recent developments. Planta Med.
2003;69(7);Suppl 7:589-99. doi: 10.1055/s-2003-41122, PMID 12898412.

27. Ososki AL, Kennelly EJ. Phytoestrogens: a review of the present state of research. Phytother Res. 2003;17(8);Suppl 8:845-69. doi: 10.1002/ptr.1364, PMID 13680814.

28. de Villiers TJ. Bone health and osteoporosis in postmenopausal women. Best Pract Res Clin Obstet Gynaecol. 2009;23(1);Suppl 1:73-85. doi: 10.1016/j.bpobgyn.2008.10.009, PMID 19027366.

29. Muchtaridi M, Dermawan D, Yusuf M. Molecular docking, 3D structure-based pharmacophore modeling, and ADME prediction of alpha mangostin and its derivatives against estrogen receptor alpha. J Young Pharm. 2018;10(3);Suppl 3:252-9. doi: 10.5530/jyp.2018.10.58.

30. Nogara PA, Saraiva Rde A, Caeran Bueno D, Lissner LJ, Lenz Dalla Corte C, Braga MM, Rosemberg DB, Rocha JB. Virtual screening of acetylcholinesterase inhibitors using the Lipinski's rule of five and ZINC databank. BioMed Res Int. 2015;2015:870389. doi: 10.1155/2015/870389. PMID 25685814.

31. Daina A, Zoete V. A BOILED-egg to predict gastrointestinal absorption and brain penetration of small molecules. ChemMedChem. 2016;11(11):1117-21. doi: 10.1002/cmdc.201600182, PMID 27218427.

32. Chagas CM, Moss S, Alisaraie L. Drug metabolites and their effects on the development of adverse reactions: revisiting Lipinski's Rule of five. Int J Pharm. 2018;549(1-2):133-49. doi: 10.1016/j.ijpharm.2018.07.046, PMID 30040971.

33. Meyer MR, Prossnitz ER, Barton M. The G protein-coupled estrogen receptor GPER/GPR30 as a regulator of cardiovascular function. Vasc Pharmacol. 2011 [Suppl:1725:17-25];55(1-3):17-25. doi: 10.1016/j.vph.2011.06.003.

34. Lee RR, Phillips KP. Role of estrogen receptors in male reproductive physiology. RISS-IJHS. 2013;3(1);Suppl 1:40-5. doi: 10.18192/riss-ijhs.v3i1.1452.

35. Liu EYL, Xu ML, Jin Y, Wu Q, Dong TTX, Tsim KWK. Genistein, a phytoestrogen in soybean, induces the expression of acetylcholinesterase via $G$ protein-coupled receptor 30 in PC12 cells. Front Mol Neurosci. 2018;11:1-11.

36. Zhang Z, Qin P, Deng Y, Ma Z, Guo H, Guo H, Hou Y, Wang S, Zou W, Sun Y, Ma Y, Hou W. The novel estrogenic receptor GPR30 alleviates ischemic injury by inhibiting TLR4-mediated microglial inflammation. J Neuroinflammation. 2018;15(1);Suppl 1:1-13:206. doi: 10.1186/s12974-0181246-x, PMID 30001721. 